\title{
Impact of brine-induced stratification on the glacial carbon cycle
}

\author{
N. Bouttes ${ }^{1}$, D. Paillard ${ }^{1}$, and D. M. Roche ${ }^{1,2}$ \\ ${ }^{1}$ Laboratoire des Sciences du Climat et de l'Environnement, IPSL-CEA-CNRS-UVSQ, UMR 8212, Centre d'Etudes de \\ Saclay, Orme des Merisiers bat. 701, 91191 Gif Sur Yvette, France \\ ${ }^{2}$ Faculty of Earth and Life Sciences, Section Climate Change and Landscape dynamics, Vrije Universiteit Amsterdam, \\ De Boelelaan, 1085, 1081 HV Amsterdam, The Netherlands
}

Received: 26 March 2010 - Published in Clim. Past Discuss.: 26 April 2010

Revised: 23 August 2010 - Accepted: 31 August 2010 - Published: 15 September 2010

\begin{abstract}
During the cold period of the Last Glacial Maximum (LGM, about 21000 years ago) atmospheric $\mathrm{CO}_{2}$ was around $190 \mathrm{ppm}$, much lower than the pre-industrial concentration of $280 \mathrm{ppm}$. The causes of this substantial drop remain partially unresolved, despite intense research. Understanding the origin of reduced atmospheric $\mathrm{CO}_{2}$ during glacial times is crucial to comprehend the evolution of the different carbon reservoirs within the Earth system (atmosphere, terrestrial biosphere and ocean). In this context, the ocean is believed to play a major role as it can store large amounts of carbon, especially in the abyss, which is a carbon reservoir that is thought to have expanded during glacial times. To create this larger reservoir, one possible mechanism is to produce very dense glacial waters, thereby stratifying the deep ocean and reducing the carbon exchange between the deep and upper ocean. The existence of such very dense waters has been inferred in the LGM deep Atlantic from sediment pore water salinity and $\delta^{18} \mathrm{O}$ inferred temperature. Based on these observations, we study the impact of a brine mechanism on the glacial carbon cycle. This mechanism relies on the formation and rapid sinking of brines, very salty water released during sea ice formation, which brings salty dense water down to the bottom of the ocean. It provides two major features: a direct link from the surface to the deep ocean along with an efficient way of setting a strong stratification. We show with the CLIMBER-2 carbon-climate model that such a brine mechanism can account for a significant decrease in atmospheric $\mathrm{CO}_{2}$ and contribute to the glacial-interglacial change. This mechanism can be amplified by low vertical diffusion resulting from the brine-induced stratification. The modeled glacial dis-
\end{abstract}

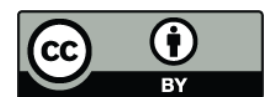

Correspondence to: N. Bouttes (nathaelle.bouttes@1sce.ipsl.fr) tribution of oceanic $\delta^{13} \mathrm{C}$ as well as the deep ocean salinity are substantially improved and better agree with reconstructions from sediment cores, suggesting that such a mechanism could have played an important role during glacial times.

\section{Introduction}

Proxy data suggest that the climate of the Last Glacial Maximum (LGM, about 21000 years ago) was very cold ( -2 to $-6^{\circ} \mathrm{C}$ in the Southern Ocean surface (MARGO Project Members, 2009)) with huge Northern Hemisphere ice sheets (Peltier, 2004). The associated carbon cycle was characterized by low atmospheric $\mathrm{CO}_{2}$ concentrations of $\sim 190 \mathrm{ppm}$ (Monnin et al., 2001) and very negative deep ocean $\delta^{13} \mathrm{C}$. The latter is based on the stable carbon isotopic composition $\left(\delta^{13} \mathrm{C}\right)$ of benthic foraminifera which is assumed to reflect the $\delta^{13} \mathrm{C}$ of total dissolved inorganic carbon (DIC) in bottom waters.

The Atlantic $\delta{ }^{13} \mathrm{C}$ reached low values down to $-0.8 \%$ in the deep ocean participating in a higher upper to deep oceanic gradient (Duplessy et al., 1988; Curry and Oppo, 2005; Köhler and Bintanja, 2008). The mean upper $(-2000 \mathrm{~m}$ to $0 \mathrm{~m})$ to deep $(-5000 \mathrm{~m}$ to $-3000 \mathrm{~m})$ gradient in the Atlantic, (noted $\Delta \delta^{13} \mathrm{C}_{\text {atl }}$ ), was about $1.2 \%$ in the Atlantic, compared to only $0.4 \%$ o during the pre-industrial.

LGM climate can be explained by the extended ice sheets in connection with a different orbital configuration (Berger, 1978) and lower $\mathrm{CO}_{2}$ (Jahn et al., 2005). To explain the crucial question of the low glacial $\mathrm{CO}_{2}$ numerous hypotheses have been proposed. Some of them imply changes of physical mechanisms such as modifications of sea ice coverage (Stephens and Keeling, 2000) or winds (Toggweiler et al., 2006). Many have focused on enhancing

Published by Copernicus Publications on behalf of the European Geosciences Union. 
or making more efficient the marine biology, for example through higher C/P ratio (Broecker and Peng, 1982), iron fertilization (Martin, 1990), a shift of dominant plankton species (Archer and Maier-Reimer, 1994), larger nutrients availability (Matsumoto et al., 2002), or modified rain ratio (Brovkin et al., 2007). Other studies have involved coral reef fluctuations (Berger, 1982; Opdyke and Walker, 1992), or oceanic chemistry with carbonate compensation (Broecker and Peng, 1987). But most only have a small impact on $\mathrm{CO}_{2}$ compared to the glacial-interglacial change, or would require unrealistic modifications to become dominant (Archer et al., 2000, 2003; Kohfeld et al., 2005; Menviel et al., 2008b). Moreover, it has remained especially difficult to correctly simulate simultaneously the very negative $\delta^{13} \mathrm{C}$ in the deep ocean inferred from marine sediment cores, although part of the change is due to the glacial reduced terrestrial biosphere which releases light ${ }^{12} \mathrm{C}$ leading to a reduction of the global mean oceanic $\delta^{13} \mathrm{C}$ (Köhler et al., 2010). Additionally, the strong link between Antarctic temperatures and atmospheric $\mathrm{CO}_{2}$ variations (Luthi et al., 2008) suggests that mechanisms closely tied to Southern Ocean surface processes are likely to be dominant in controlling atmospheric $\mathrm{CO}_{2}$ variability.

The general consensus is that the ocean is at the core of the solution regarding $\mathrm{LGM} \mathrm{CO}_{2}$. It is the biggest carbon reservoir active on the short time scale studied (a few thousand years) and the only one that could increase during glacial times, since the other two reservoirs, i.e., the atmosphere (Monnin et al., 2001) and terrestrial biosphere (Bird et al., 1994; Crowley, 1995), were both reduced. Observations indicate that the deep glacial ocean was much saltier and colder than today (Adkins et al., 2002), thus more stratified in the abyss. Such a deep stratification has important impacts on the ocean's circulation and carbon cycle, as pointed out by climate models of different complexities (Toggweiler, 1999; Paillard and Parrenin, 2004; Köhler et al., 2005a; Bouttes et al., 2009; Tagliabue et al., 2009). In particular, deep stratification is required to reconcile $\delta^{13} \mathrm{C}$ (Bouttes et al., 2009; Tagliabue et al., 2009). However, only box models could significantly reduce atmospheric $\mathrm{CO}_{2}$ when prescribing a reduced Southern ventilation (Watson and Garabato, 2005). With models of higher complexity (Bouttes et al., 2009; Tagliabue et al., 2009) the induced $\mathrm{CO}_{2}$ drop remained too small which highlights the need of another mechanism that would still maintain the benefits of deep stratification (deep negative $\delta^{13} \mathrm{C}$ values) while reducing $\mathrm{CO}_{2}$ more drastically.

Here we test the impact of the formation and rapid deep sinking of brines, i.e. very salty waters rejected during sea ice formation, on the glacial carbon cycle. The role of brines has been previously proposed as an explanation for the reduced Southern ventilation (Paillard and Parrenin, 2004; Köhler et al., 2005a; Watson and Garabato, 2005), but they were not explicitly simulated. Instead, the proposed effect of reducing the ventilation was tested by imposing lower mixing in box models only. Here we directly test this mechanism with a more complex model which physically includes advection and diffusion in the ocean and thus is able to reproduce the dynamical effect of brines. Because they are enriched in salt, these "pockets of water" are very dense. In the modern Antarctic they are generally mixed with fresh water from ice shelf melting (Joughin and Padman, 2003). However, during the glacial periods the sea level progressively fell (down to about $120 \mathrm{~m}$ at the Last Glacial Maximum) and the northward Antarctic ice sheet extent resulted in a progressive reduction of the shelf slope (Ritz et al., 2001) where modern waters are mixed. Tidal dissipation, which is important in today's mixing, would then seriously decrease. Accordingly, the brine signal, which is diluted today, would be more preserved at the LGM. Furthermore, the sea ice formation location would also shift northward and closer to the continental shelf break. The preserved brine-dense water, whose volume was increased because of enhanced sea ice formation, would arrive at the shelf break and then flow quickly down the slope (helped by thermobaricity and supercritical flux properties) (Foldvik et al., 2004). This mechanism (referred herein thereafter as the brine mechanism) provides two major features: a direct link from the surface to the deep ocean and an effective physical way of achieving a strong stratification. In this study we test its impact on the carbon cycle and compare the modeled results to atmospheric $\mathrm{CO}_{2}$, oceanic $\delta^{13} \mathrm{C}$ and salinity data inferred from ice core and marine sediment cores.

\section{Methods}

\subsection{CLIMBER-2 model}

The brine mechanism has been implemented and tested in CLIMBER-2, an intermediate complexity climate model (Petoukhov et al., 2000) well suited for the long term simulations we run. Indeed, the simulations are run for 20000 years to ensure the equilibrium of the carbon cycle. Moreover we realize an ensemble of about 100 simulations to test the mechanism, which would be unfeasible with a general circulation model (GCM) in a reasonable amount of time. The intermediate complexity model, although simpler than a state of the art OGCM, includes the main known processes and mechanisms and computes the dynamics of the oceanic circulation contrary to box models. Furthermore, like GCMs, CLIMBER-2 does not exhibit box model sensitivity to highlatitude sea ice or presumably stratification (Archer et al., 2003). Additionally, the model compares favourably with a state of the art OGCM and gives the same response in terms of carbon cycle when the circulation is arbitrarily modified (Tagliabue et al., 2009).

CLIMBER-2 has a coarse resolution of $10^{\circ}$ in latitude by $51^{\circ}$ in longitude in the atmosphere, and 21 depth levels by $2.5^{\circ}$ latitude in the zonally averaged ocean, which is precise enough to take into account geographical changes, while 
allowing the model to be fast enough to run the long simulations considered. The model is composed of various modules simulating the ocean, the atmosphere, and the continental biosphere dynamics. No sediment model is included, the model thus does not take into account the carbonate compensation mechanism. CLIMBER-2 has already been used and evaluated in previous studies (Ganopolski et al., 2001a; Brovkin et al., 2002a,b, 2007; Bouttes et al., 2009). As the model version used explicitly computes the evolution of the carbon cycle and carbon isotopes (such as $\delta^{13} \mathrm{C}$ ) in every reservoirs, it allows us to compare the model output with data from sediment cores. In the glacial simulations three boundary conditions are simultaneously imposed: the ice sheets (Peltier, 2004), the solar insolation (Berger, 1978), and the atmospheric $\mathrm{CO}_{2}$ concentration for the radiative forcing (190 ppm, not used in the carbon cycle part of the model) (Monnin et al., 2001). To account for the glacial sea level fall of about $120 \mathrm{~m}$, salinity and nutrients $\left(\mathrm{NO}_{3}^{-}\right.$and $\left.\mathrm{PO}_{4}^{2-}\right)$ mean concentrations are increased by $3.3 \%$.

\subsection{Implementation of brines in the CLIMBER-2 model}

When sea ice is formed, a flux of ions is released into the ocean as sea ice is mostly composed of fresh water (Wakatsuchi and Ono, 1983; Rysgaard et al., 2007, 2009). Because the underlying water is then enriched in salt it becomes denser and can thus sink and transport salt to deeper waters. The rejection of salt by sea ice formation plays an important role in the formation of deep water, as it is the case for the Antarctic Bottom Water (AABW) which has been studied for a few decades (Foster and Carmack, 1976; Whitworth and Nowlin, 1987; Foldvik et al., 2004; Nicholls et al., 2009). The brine mechanism has been mostly observed in details in the Northern Hemisphere oceans (Haarpaintner et al., 2001; Shcherbina et al., 2003; Skogseth et al., 2004, 2008), where measures are easier than in the Southern Ocean. For instance, measures in the Arctic fjords indicate that approximately $78 \%$ of the brine-enriched shelf water was released out of the fjord in the Norwegian Sea (Haarpaintner et al., 2001 ), i.e. around $62 \%$ of the salt flux rapidly released by sea ice formation (the first rapid salt release is $\sim 82 \%$ of the total salt flux rejected by sea ice formation). The impact of the brine formation on the concentration of other geochemical variables, especially dissolved inorganic carbon (DIC) has also been studied and it has been shown that DIC is rejected together with brine from growing sea ice (Rysgaard et al., 2007, 2009). Besides, numerical studies of this local mechanism show that the topography plays an important role in the transport of salt (Kikuchi et al., 1999).

Thus although today the brine formation around Antarctica does not affect the bottom waters (Toggweiler and Samuels, 1995), the formation and sinking of brines is a mechanism that can be observed and studied in some places of the modern ocean and that strongly depends on local conditions. The inferred higher salinity in the glacial Southern
Ocean seems to indicate that enhanced brine formation and sinking could well have taken place around Antarctica during glacial conditions, which should be tested.

In order to assess the potential impact of the sinking of brines on the carbon cycle we need to use a global carbonclimate model. Yet the spatial resolution of such models, even state of the art GCMs, is too large to resolve the brine sink, requesting a parameterization. We thus develop a simple parameterization for this mechanism. The simplicity of the scheme used permits a first evaluation of such a mechanism and allows a separation of the different processes to understand the reasons of the changes observed.

The sinking of brines initially depends on the amount of salt rejected which is determined by the rate of sea ice formation. In CLIMBER-2, sea ice formation is computed by a one layer thermodynamic sea ice model with a simple parameterization for horizontal ice transport (Brovkin et al., 2007). The sea ice extent is increased in winter in agreement with proxy data (Gersonde et al., 2005) although during summer sea ice extent is also increased contrary to the data which indicate a sea ice covered area similar to the modern one.

During the formation of sea ice, in the standard version of CLIMBER-2 only the flux of salt $\left(F_{\mathrm{S}}\right)$ was considered. It is usually a good approximation on the first order, yet the release of other ions and dissolved gases could be of importance for this study. Hence we have added the same process as the release of salt for the other ions and dissolved gases simulated in the model (dissolved inorganic carbon (DIC), alkalinity (ALK), nutrients, dissolved organic carbon, oxygen, $\mathrm{DI}^{13} \mathrm{C}, \mathrm{DI}^{14} \mathrm{C}$ ). As a first approximation the surface oceanic cell is enriched in these geochemical variables in the same proportion as salt as it has been observed to be not very different on the first order (Rysgaard et al., 2007, 2009). The flux $\left(F_{X}\right)$ of any geochemical variable $X$ rejected during sea ice formation to the surface ocean is then:

$F_{X}=\frac{F_{\mathrm{S}}}{S_{\text {surface }}} \cdot X_{\text {surface }}$

With $F_{\mathrm{S}}$ the flux of salt, $S_{\text {surface }}$ the surface salinity, and $X_{\text {surface }}$ the surface concentration of any geochemical variable.

This process is active in all simulations, though it has a small impact on the standard pre-industrial and LGM simulations (atmospheric $\mathrm{CO}_{2}$ is changed by less than $5 \mathrm{ppm}$ ).

In the standard version of CLIMBER-2 when sea ice is formed all the salt is released in the corresponding surface oceanic cell, which is relatively large according to the coarse resolution of the model and thus dilutes the brine signal. In the brine simulations, a fixed fraction (frac) of this salt flux (and of the other ions flux) will form the sinking brines (Fig. 1a). This fraction frac can be set to 0 when none of the salt sinks to the bottom of the ocean (standard version of the model) and 1 when all the salt is used in the brine mechanism. The very salty (thus dense) brine water sinks to the bottom of the ocean where it modifies the concentration of 

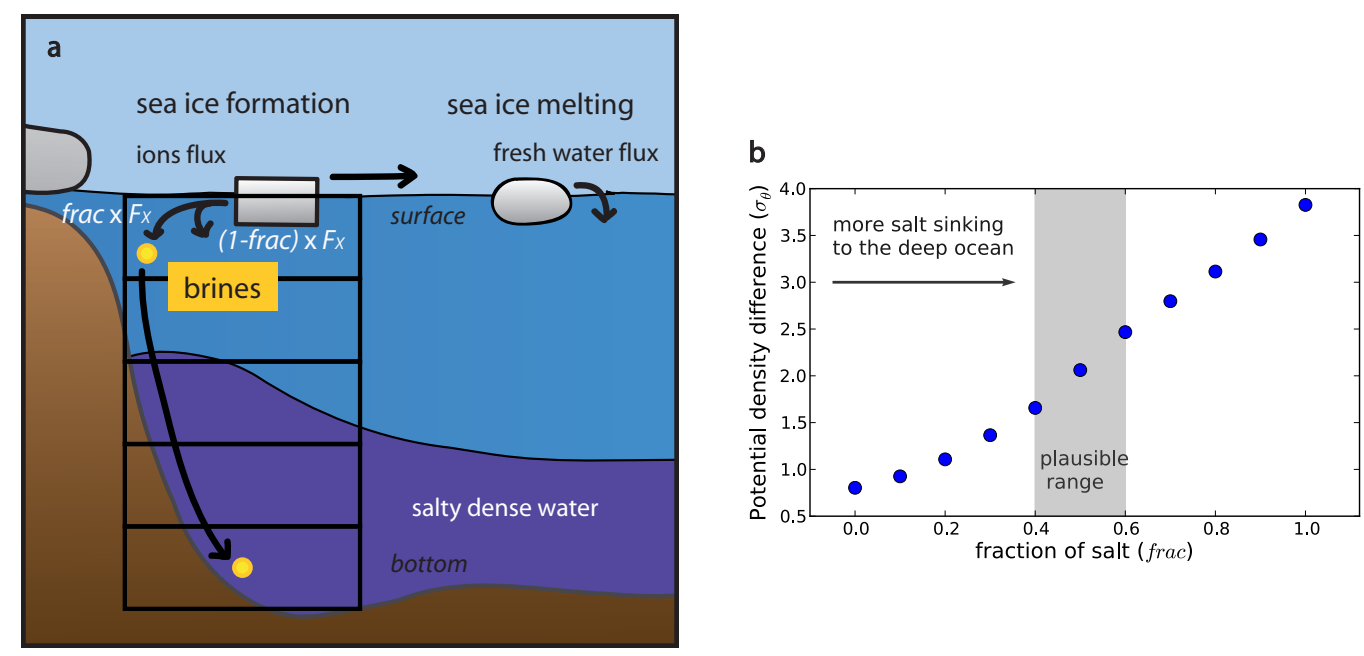

Fig. 1. (a) Brine sinking mechanism scheme and (b) Potential density difference between the deep Atlantic ocean (between $-5000 \mathrm{~m}$ and $-3000 \mathrm{~m}$ ) and the upper Atlantic ocean (between $-2000 \mathrm{~m}$ and $0 \mathrm{~m}$ ) as a function of the fraction of salt released by sea ice formation used for the brine mechanism (fraction of salt frac, $0 \leq$ frac $\leq 1$ ). (a) When sea ice is formed salt and other modeled ions (and dissolved gases), such as dissolved inorganic matter (DIC), alkalinity (ALK), dissolved organic carbon (DOC), nutrients, oxygen, $\mathrm{DI}^{13} \mathrm{C}$ and $\mathrm{DI}{ }^{14} \mathrm{C}$ are released into the surface ocean beneath as a flux $\left(F_{X}\right.$ which is the flux of variable $\left.X\right)$. A fraction of this flux $\left(f r a c \cdot F_{X}\right)$ is dedicated to the brine sinking mechanism and is directly transported to the deep ocean instead of being diluted in the surface cell as the rest of the flux $\left((1-f r a c) \cdot F_{X}\right)$. This mechanism both creates a link from the surface to the deep ocean and sets an efficient deep ocean stratification as the vertical density gradient increases (b).

any geochemical variable $X$ (salinity, DIC, ALK, nutrients, dissolved organic carbon, oxygen, $\mathrm{DI}^{13} \mathrm{C}$ and $\mathrm{DI}^{14} \mathrm{C}$ ) as following:

$V_{\text {bottom }} \frac{d X_{\text {bottom }}}{d t}=\mathrm{frac} \cdot F_{X} \cdot$ area

With $V_{\text {bottom }}$ the volume of the bottom cell, $X_{\text {bottom }}$ the concentration of $X$ at the bottom and area the area of the surface cell. At the surface the rest of the ion flux from sea ice formation not sinking with brines $\left((1-f r a c) \cdot F_{X}\right)$ is diluted in the surface cell. The geochemical variables are thus modified as following:

$V_{\text {surface }} \frac{d X_{\text {surface }}}{d t}=(1-\mathrm{frac}) \cdot F_{X} \cdot$ area

Even if this brine mechanism is idealized, it reflects the impact of intense Antarctic sea ice formation during the LGM. As the glacial Antarctic ice sheet extends close to the limit of the continental shelf, sea ice formation enhanced by the strong katabatic winds happens close to the continental slope. The brines formed by the coeval salt rejection can then rapidly sink along the continental slope down to the deep ocean. Unlike convection, the brine mechanism directly transports this fraction of salt and other ions $\left(\mathrm{frac} \cdot F_{X}\right)$ to the deep ocean, and thus represents a direct link from the surface to the bottom of the ocean. Because of the salt transport to the deep ocean this mechanism leads to enhanced stratification of the ocean as the density gradient between the deep and upper ocean increases (Fig. 1b).

We present model results and compare them to the main carbon data available for the LGM, e.g. atmospheric $\mathrm{CO}_{2}$ concentration and $\delta^{13} \mathrm{C}$ distribution in the ocean, which constitute a major constraint with which to validate this mechanism. We also compare model results to the glacial deep ocean salinity and $\Delta^{14} \mathrm{C}$.

\section{Results and discussion}

\subsection{Standard simulation}

The CLIMBER-2 version used here has a closed carbon cycle i.e. the total (fixed) amount of carbon is interactively distributed between the three reservoirs (atmosphere, terrestrial biosphere and ocean) (Brovkin et al., 2002a), and the model does not include carbonate compensation. From the pre-industrial value of $280 \mathrm{ppm}$, atmospheric $\mathrm{CO}_{2}$ rises to $296 \mathrm{ppm}$ for the standard glacial simulation (LGM-std, Fig. 2a). This $\mathrm{CO}_{2}$ rise is due to the prevailing effect of increased ocean salinity and terrestrial vegetation decline (of approximately $700 \mathrm{GtC}$ ) which increase $\mathrm{CO}_{2}$, despite increased nutrient concentration (linked to sea level drop) and colder sea surface temperatures which decrease $\mathrm{CO}_{2}$. This modeled $16 \mathrm{ppm}$ increase adds to the observed $90 \mathrm{ppm}$ 
a

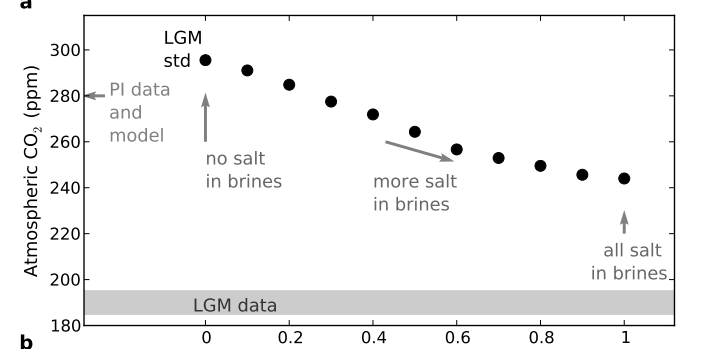

b

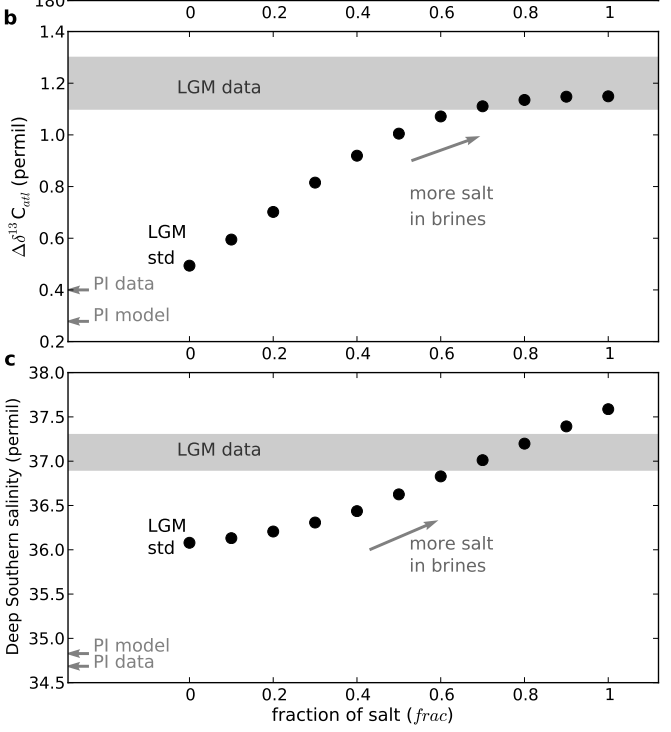

Fig. 2. (a) Atmospheric $\mathrm{CO}_{2}$ concentration, (b) $\Delta \delta^{13} \mathrm{C}_{\mathrm{atl}}$ (mean upper $(-2000 \mathrm{~m}$ to $0 \mathrm{~m})$ to deep $(-5000 \mathrm{~m}$ to $-3000 \mathrm{~m})$ gradient in the Atlantic) and (c) salinity in the deep Southern ocean (Atlantic sector, 50 degrees South, $3626 \mathrm{~m}$ depth) as a function of the fraction of salt released by sea ice formation used for the brine mechanism (fraction of salt frac, $0 \leq$ frac $\leq 1$ ). frac $=0$ corresponds to the standard simulations without any brine mechanism (all the salt and ions are diluted in the surface cell where sea ice is formed). When frac $=1$ all the released salt and other ions sink with the brine mechanism down to the abyss. The Last Glacial Maximum (LGM) and Pre-industrial (PI) data are from Monnin et al., 2001; Curry and Oppo, 2005; Köhler and Bintanja, 2008; Adkins et al., 2002.

drop between the Pre-industrial and the LGM and means the total required simulated LGM drawdown is $106 \mathrm{ppm}$ $\left(\Delta \mathrm{CO}_{2}\right)$. The simulated oceanic $\delta^{13} \mathrm{C}$ distribution is different from the reconstructed one, in particular the simulated upper to bottom $\delta^{13} \mathrm{C}$ gradient $\left(\Delta \delta^{13} \mathrm{C}_{\mathrm{atl}}\right)$ is around $0.5 \%$ o compared to the data value of about $1.2 \%$ (Fig. 2b). Finally the simulated salinity in the deep Southern Ocean (Fig. 2c) lies well below the data value of around $37.1 \mathrm{psu}$ measured in a sediment core (Shona Rise, $49^{\circ} \mathrm{S}, 3626 \mathrm{~m}$ depth) (Adkins et al., 2002). This mismatch between model results and data indicate the need for a mechanism which would increase the deep Southern salinity (the global mean increase of salinity due to sea level fall is already taken into account in all simulations) and lower the deep $\delta^{13} \mathrm{C}$ thus probably changing
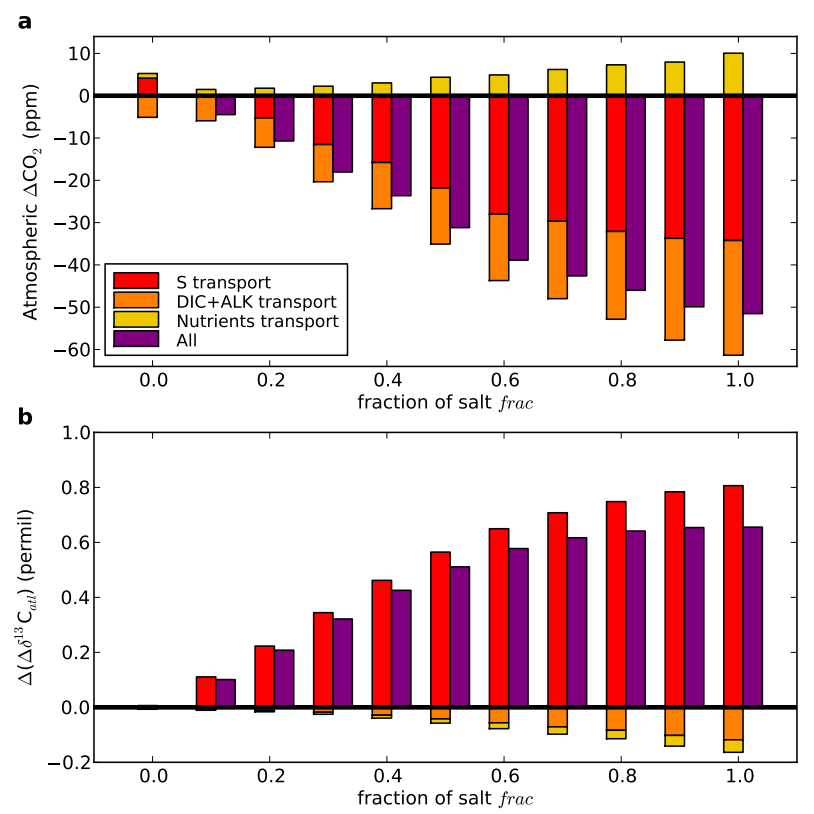

Fig. 3. (a) Atmospheric $\mathrm{CO}_{2}$ change $\left(\Delta \mathrm{CO}_{2}\right)$ and (b) $\Delta \delta^{13} \mathrm{C}_{\mathrm{atl}}$ change $\left(\Delta\left(\Delta \delta^{13} \mathrm{C}_{\mathrm{atl}}\right)\right)$ due to the transport of salt (S), dissolved inorganic carbon (DIC) and alkalinity (ALK), nutrients, and dissolved organic carbon (DOC, too small too be visible, less than $1 \mathrm{ppm}$ ). In all simulations the transport of salt is activated. In the "S transport" experiment only salt is transported, in "DIC+ALK transport" salt, DIC and ALK are transported, in "Nutrients transport" salt and nutrients are transported. "All" is the effect of the simultaneous transport of all variables. $\triangle \mathrm{CO}_{2}$ is the difference between the modeled $\mathrm{CO}_{2}$ and the standard modeled $\mathrm{CO}_{2}$ (LGM std, $\mathrm{CO}_{2}=296 \mathrm{ppm}$ ). $\Delta\left(\Delta \delta^{13} \mathrm{C}_{\mathrm{atl}}\right)$ is the difference between the modeled $\Delta \delta^{13} \mathrm{C}_{\mathrm{atl}}$ and the standard modeled $\Delta \delta^{13} \mathrm{C}_{\text {atl }}$ (LGM std).

oceanic circulation. The brines seem to be a good candidate as they will bring saline water to the abyss which will increase deep water salinity. In the following we will assess the impact of the brines and compare with data to either validate or reject such a possibility.

\subsection{Atmospheric $\mathrm{CO}_{2}$ drawdown induced by the brine mechanism}

The sinking of brines can have a very large effect on atmospheric carbon in our simulations (Fig. 2a). Atmospheric $\mathrm{CO}_{2}$ progressively decreases when the fraction of salt frac that sinks to the abyss increases. The frac $=0$ simulation (no brine mechanism) corresponds to the standard LGM simulation (LGM-std), where $\mathrm{CO}_{2}$ is $296 \mathrm{ppm}$. The maximum effect of the brines is obtained for frac $=1$, i.e. when all the salt released by sea ice formation sinks to the bottom of the ocean with the brine mechanism. The latter gives a maximum $\mathrm{CO}_{2}$ drop of about $52 \mathrm{ppm}\left(\mathrm{CO}_{2}\right.$ is $\left.244 \mathrm{ppm}\right)$. In this case it takes approximately 3000 years for the model to gain steady state 

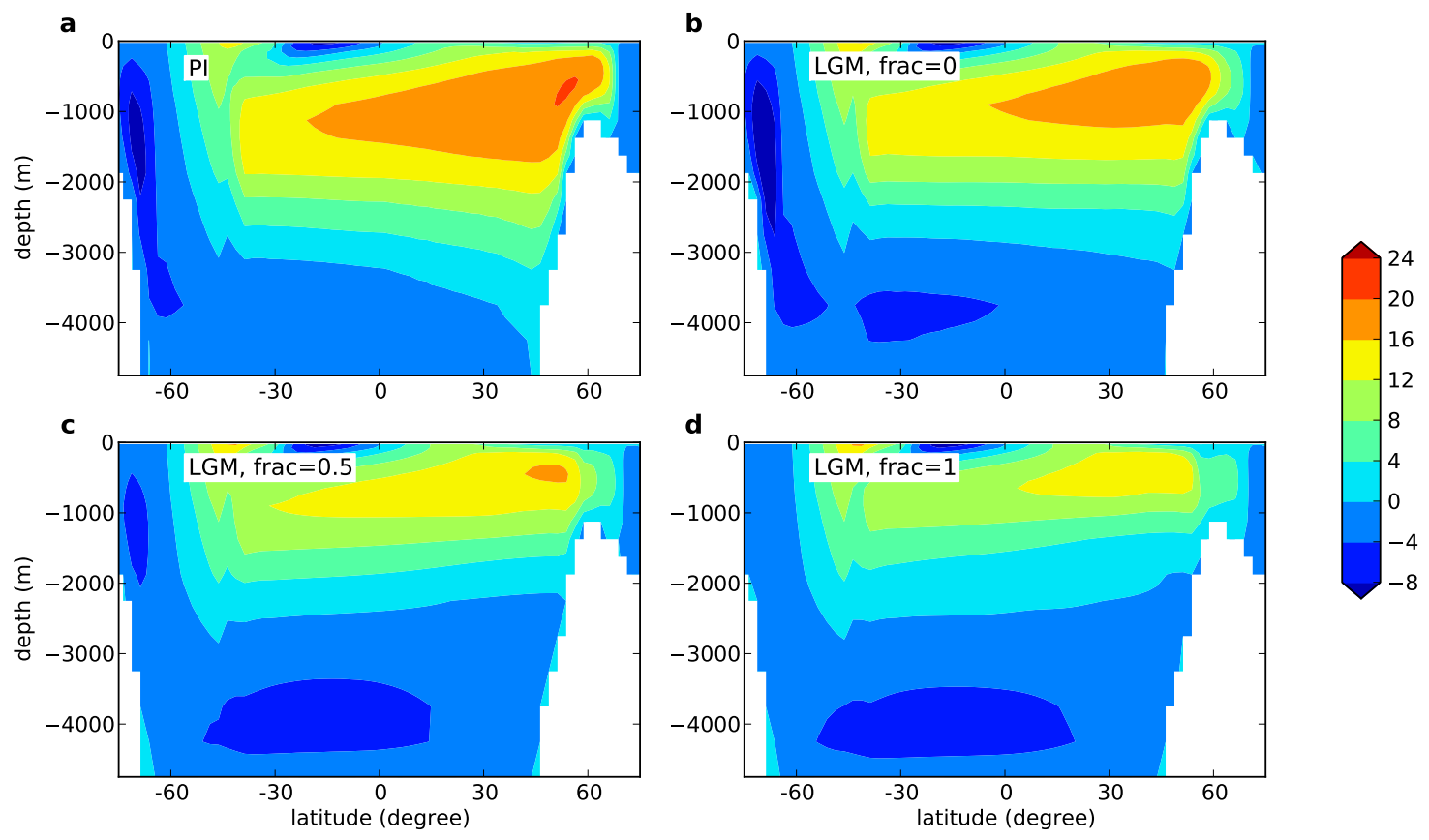

Fig. 4. Simulated meridional overturning stream function (Sv) in the Atlantic for (a) the Pre-industrial (PI) simulation, (b) the standard LGM simulation (LGM-std) with frac $=0$ (no impact of brines), (c) the LGM simulation with frac $=0.5$ (medium impact of brines), (d) the LGM simulation with $f r a c=1$ (maximum impact of brines).

again after the onset of the sinking of brines, as the ocean circulation has to adapt to the induced change of density distribution (Fig. 1b).

To understand the reasons of the atmospheric $\mathrm{CO}_{2}$ drawdown, we first assess which variable transport is a major contributor to these changes (Fig. 3a). We explore the impact of the sinking of salt alone, then we add either dissolved inorganic carbon (DIC) and alkalinity (ALK), nutrients (phosphate and nitrate) or dissolved organic carbon (DOC). The transport of salt is activated in all simulations as it is the initial reason for the sinking of the brines.

First we consider only the transport of salt to the deep ocean; the other variables do not sink with the brines. The salt sink accounts for the largest part of the $\mathrm{CO}_{2}$ drop (approximately $60 \%$ of the $\mathrm{CO}_{2}$ drawdown due to the brine mechanism, Fig. 3a). The increased salinity of the bottom waters results in higher upper to deep ocean density difference (Fig. 1b). Hence the deep stratification is enhanced and the oceanic circulation modified (Fig. 4). In the standard glacial simulation the atlantic meridional overturning circulation is slightly different from the pre-industrial one. The upper branch is shallower while the lower branch more intense and penetrates farther north (Fig. $4 a$ and b). With the sinking of salt the vertical density gradient is higher. This leads to a more reduced upper branch while the lower branch expands upwards (Fig. $4 \mathrm{c}$ and d). The ventilation of the lower branch is reduced resulting in a decoupling between upper and deep waters. The carbon enriched Antarctic Bottom Water $(\mathrm{AABW})$ is less mixed with the surrounding waters and constitutes a greater volume of water. The trapping of $\mathrm{CO}_{2}$ released from the remineralization of organic matter in the deep ocean is then more efficient. The deep carbon reservoir has thus expanded thanks to the change of circulation induced by the salt transport alone.

The transport of dissolved inorganic carbon (DIC) and alkalinity (ALK) by brines also plays a role as it further decreases atmospheric $\mathrm{CO}_{2}$ (Fig. 3). The direct transport of DIC and ALK to the abyss helps building an increased deep oceanic carbon reservoir as carbon is brought to the deep ocean but can not escape because of the stratification set by the increased density. In these sensitivity experiments, salt, DIC and ALK are transported. If only DIC and ALK were transported, the $\mathrm{CO}_{2}$ change would be much greater, but with the salt transport the DIC and ALK concentrations in the surface are already depleted so that the effect of transporting DIC and ALK is not as effective.

The transport of nutrients has an opposite effect, as their transport to the abyss decreases their surface concentrations and thus the biological activity (Fig. 3). The biological pump being less efficient, less atmospheric $\mathrm{CO}_{2}$ is taken up by the ocean. Yet this effect is smaller than the two previous ones. Additionaly the transport of DOC is negligible compared to the other mechanisms (less than $1 \mathrm{ppm}$ ). 
Now that we have seen that the salt sink is the main driver of the $\mathrm{CO}_{2}$ drop and that the DIC and ALK transport can also play a role, we investigate how they impact the atmospheric $\mathrm{CO}_{2}$. Because of the direct effect of the salt sink (transport from the surface to the bottom) and indirect effect (change of oceanic circulation because of the stratification) the distribution of salinity, DIC and ALK in the ocean is modified (especially the repartition between surface and deep waters). The changed surface concentrations modify the oceanic dissolved $\mathrm{CO}_{2}$ which ultimately drives atmospheric $\mathrm{CO}_{2}$.

Because of the salt transport by brines, salinity is increased in the deep ocean (Fig. 2c) and decreased in the surface. As the solubility of $\mathrm{CO}_{2}$ increases when salinity decreases it results in an atmospheric $\mathrm{CO}_{2}$ drawdown. To quantify this impact we have run the geochemical module of CLIMBER2 alone forced by the standard distribution of all variables (from the LGM-std simulation without brines) except salinity. For the latter we prescribe the distribution obtained in the simulation with brines for $f r a c=0$ to 1 . This allows us to get the $\mathrm{CO}_{2}$ change only due to the salinity distribution change. It appears that the modification of the salinity distribution generally accounts for around $1 / 4$ to a $1 / 3$ rd of the total $\mathrm{CO}_{2}$ decrease (Fig. 5).

Similarly, DIC and ALK are increased in the deep ocean and decreased in the surface (Fig. 6), both because of the salt transport induced stratification (we have seen that this is the main process) and the direct transport of DIC and ALK by brines. To assess the impact of the change of DIC and ALK distribution we realize the same test as for salinity. With the geochemical module of CLIMBER-2 we evaluate the impact of the change of distribution of DIC and ALK alone for frac $=0$ to 1 . It shows that the DIC and ALK distribution modification can generally explain between $1 / 2$ and $2 / 3$ rd of the oceanic $p \mathrm{CO}_{2}$ decrease (Fig. 5). Indeed, as the brines sink and make the deep ocean saltier, increased vertical stratification results. Southern convection (formation of Antarctic Bottom Water, AABW) is greatly reduced and very little exchange exists from the deep ocean to the surface, creating a deep isolated water mass that is enriched in DIC and ALK (while the surface is depleted, Fig. 6). With respect to oceanic $p \mathrm{CO}_{2}$, DIC and ALK changes have opposite effects (reduced surface DIC decreases $p \mathrm{CO}_{2}$, reduced ALK increases $p \mathrm{CO}_{2}$ ), but the DIC change prevails and results in a net oceanic $p \mathrm{CO}_{2}$ decrease.

\subsection{Impact of brines on oceanic $\delta^{13} \mathrm{C}$}

$\delta^{13} \mathrm{C}$ is usually used to track oceanic circulation, since their changes reflect the changes in ventilation of the different water masses (Duplessy et al., 1988; Curry and Oppo, 2005; Köhler and Bintanja, 2008). In the brine simulations, the modeled $\Delta \delta^{13} \mathrm{C}_{\mathrm{atl}}$ in the Atlantic Ocean is increased when the fraction of salt frac increases (Fig. 2b), which improves the results compared to proxy data. Several mechanisms can affect $\Delta \delta^{13} \mathrm{C}_{\mathrm{atl}}$, as biology and circulation both impact the

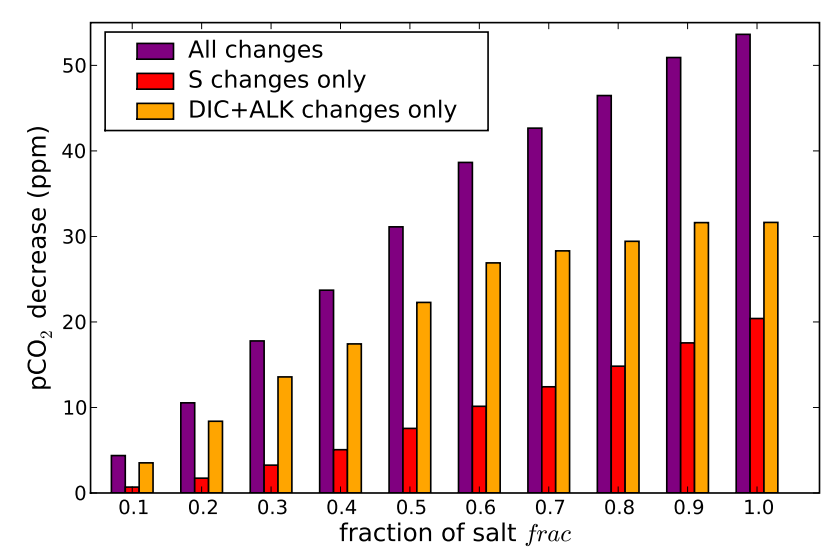

Fig. 5. Mean global ocean surface $p \mathrm{CO}_{2}$ decrease due to the brine mechanism as a function of the fraction of salt rejected by sea ice formation used for the brine mechanism (fraction of salt frac, $0 \leq$ frac $\leq 1$ ). The $p \mathrm{CO}_{2}$ is calculated from the chemical formulas of the surface ocean where the geochemical fields (salinity, temperature, DIC and ALK) are imposed and taken from the simulations with CLIMBER-2. In the $p \mathrm{CO}_{2}$ calculations (except "All changes") all the geochemical fields are from the standard LGM run (LGMstd, frac $=0$ ) except for one variable. Hence the "S changes only" (red) is the $p \mathrm{CO}_{2}$ change due to the contribution of the modification in the salinity (S) distribution only (the distribution of the other variables is the one from the standard simulation). Similarly, the "DIC + ALK changes only" (orange) corresponds to the contribution of the modification of dissolved inorganic carbon (DIC) and alkalinity (ALK) only. However, "All Changes" (purple) corresponds to the decrease due to the change of distribution of all oceanic variables.

distribution of $\delta^{13} \mathrm{C}$. Indeed, the vertical gradient of $\delta^{13} \mathrm{C}$ is primarily due the biological activity which preferentially incorporates ${ }^{12} \mathrm{C}$ during photosynthesis. This tends to deplete the upper waters of ${ }^{12} \mathrm{C}$ and hence increase $\delta^{13} \mathrm{C}$. On the opposite, when organic matter is remineralized deeper in the ocean it releases ${ }^{12} \mathrm{C}$ thus decreases the deep $\delta^{13} \mathrm{C}$. This process is then modulated by the oceanic circulation which transports and mixes water masses with different $\delta^{13} \mathrm{C}$ signatures and thus modifies the $\delta^{13} \mathrm{C}$ distribution. With the brine mechanism these two processes are involved as the salt transport alters circulation, the DIC, ALK and DOC transport directly modifies the upper and deep $\delta^{13} \mathrm{C}$ values, and the nutrients transport impacts the biological activity.

To assess the role of the salt, DIC and ALK, nutrients and DOC transport on the increase of $\Delta \delta^{13} \mathrm{C}_{\text {atl }}$ we analyze the same simulations as for $\mathrm{CO}_{2}$, when considering the transport of each of the variables (Fig. 3b). As for the $\mathrm{CO}_{2}$ decrease, the salt transport plays an important role. The $\Delta \delta^{13} \mathrm{C}_{\mathrm{atl}}$ increase is explained entirely by the salt transport. Because of the brine-induced stratification and resulting modified circulation (Fig. 4) the waters are less mixed. Hence the effect of the biological pump becomes 

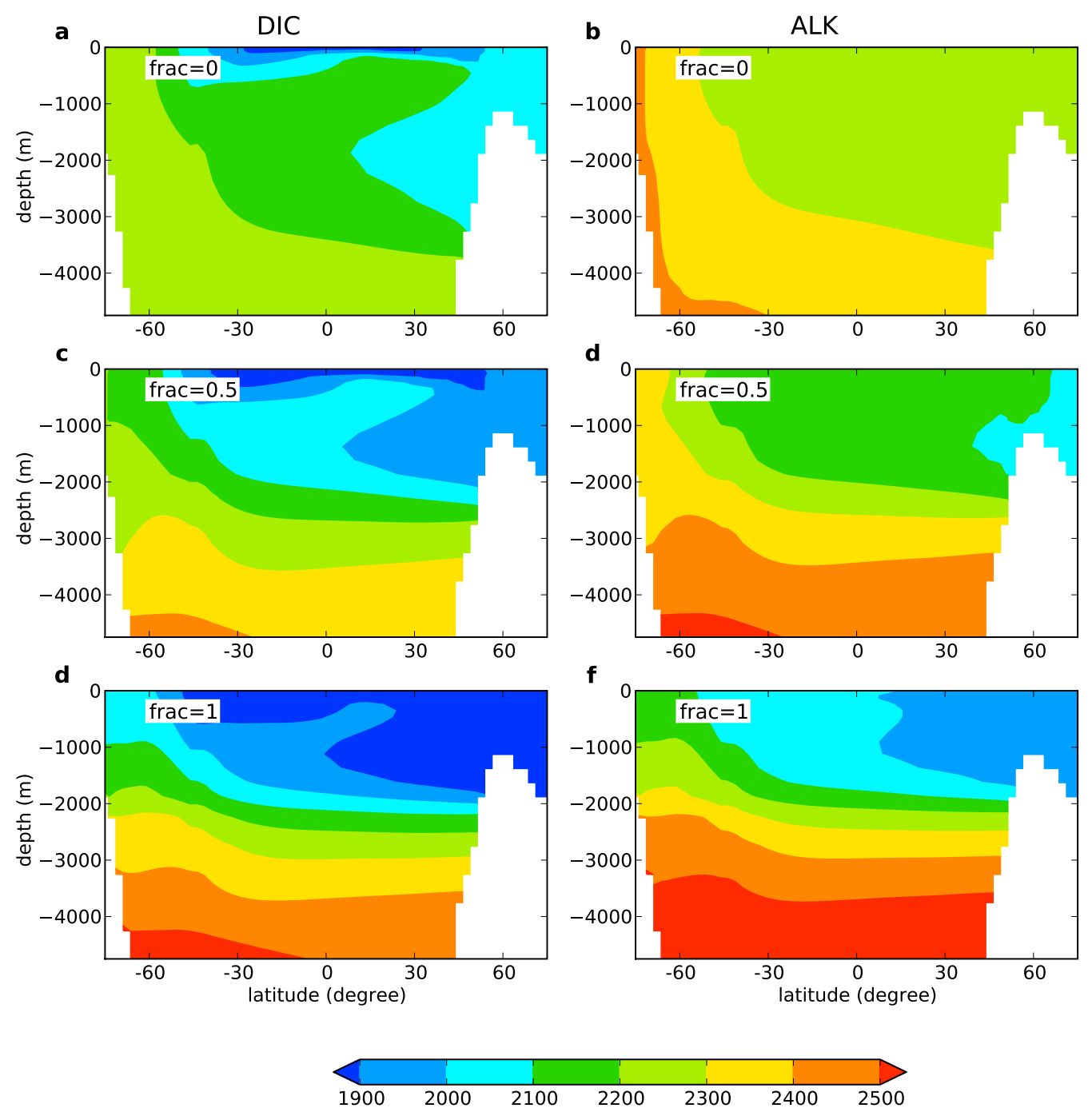

Fig. 6. (a), (c), (e) Dissolved inorganic carbon (DIC) ( $\mu \mathrm{mol} / \mathrm{kg}$ ) and (b), (d), (f) alkalinity (ALK) ( $\mu \mathrm{mol} / \mathrm{kg}$ ) distribution in the Atlantic for (a), (b) the standard simulation (LGM-std) with frac $=0$ (no impact of brines), (c), (d) frac $=0.5$ (medium impact of brines), (e), (f) frac $=1$ (maximum impact of brines).

more important compared to the mixing. The biological pump increases the vertical $\delta^{13} \mathrm{C}$ gradient. On the contrary the mixing lowers this gradient. Because the mixing is less intense the vertical gradient increases with lower deep $\delta^{13} \mathrm{C}$ and higher upper $\delta^{13} \mathrm{C}$.

The DIC and ALK transport as well as nutrient transport have an opposite yet minor effect. The DIC and ALK transport brings high surface $\delta^{13} \mathrm{C}$ values down to the bottom and tends to lower the $\Delta \delta^{13} \mathrm{C}_{\mathrm{atl}}$, but it has only a small impact of generally less than $0.1 \%$. The transport of nutrients lowers the surface nutrient concentration which decreases the biological production. As the latter is responsible for the initial $\Delta \delta^{13} \mathrm{C}_{\text {atl }}$ it also lowers $\Delta \delta^{13} \mathrm{C}_{\text {atl }}$. However this effect is negligible (less than $0.1 \%$ ). Finally the effect of DOC transport is too small to be seen.
It appears that the salt transport is clearly the main process driving the $\Delta \delta^{13} \mathrm{C}_{\mathrm{atl}}$ increase. On the contrary the other variables have only a small impact and tend to decrease $\Delta \delta^{13} \mathrm{C}_{\text {atl }}$. The $\Delta \delta^{13} \mathrm{C}_{\mathrm{atl}}$ is thus improved due to the change of circulation.

\subsection{Amplifications by low vertical diffusion}

In the previous simulations, only the impact of brines on convection and advection was taken into account via salinity changes. But it is highly probable that such changes would also reduce vertical diffusion. CLIMBER-2 prescribes vertical diffusion as a fixed vertical profile, whereas in theory it depends on the vertical density profile in the ocean. The brine induced stratification would therefore also change 


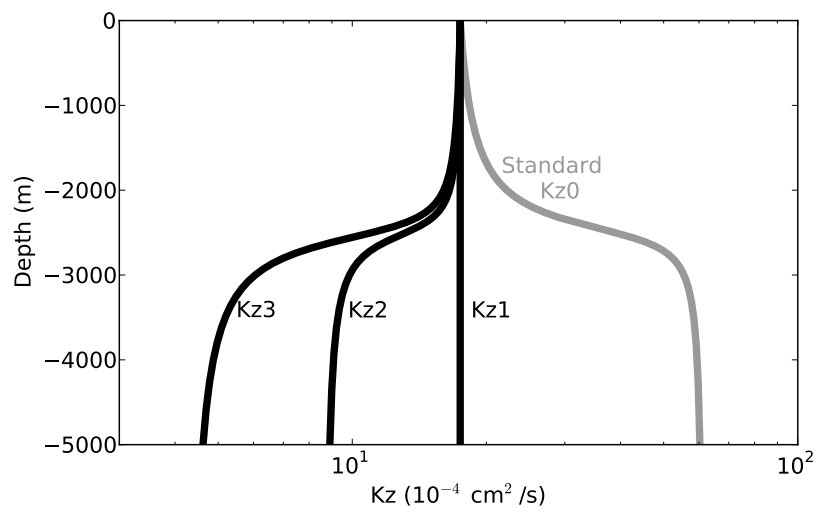

Fig. 7. Vertical diffusion coefficient profiles imposed in the simulations. $\mathrm{Kz} 0$ is the standard profile, $\mathrm{Kz} 1,2$ and 3 are the low diffusion profiles used to test the impact of deep low diffusion.

diffusion, as the more stratified the water becomes, the less vertical diffusion there would be (it requires more energy to mix well stratified water masses). To test this impact on $\mathrm{CO}_{2}$, we conduct a series of simulations with the brine mechanism where three low vertical diffusion profiles (Kz1, Kz2 and Kz3) are prescribed (Fig. 7). The impact of such low diffusion profiles alone in CLIMBER-2 has been previously studied (Bouttes et al., 2009) which showed that it helps reconcile the deep glacial $\delta^{13} \mathrm{C}$ though with a small impact on atmospheric $\mathrm{CO}_{2}$ (10 ppm decrease only). Here we test these low diffusion profiles when the brine mechanism is activated in the model. We run a set of simulations by varying the frac value between 0 and 1 for the three diffusion profiles.

The effect of low diffusion alone, that was previously analyzed, resulted in a very small impact on atmospheric $\mathrm{CO}_{2}$, which is the case for the frac $=0$ simulations. When combined with brines, the brine induced $\mathrm{CO}_{2}$ decline is amplified and it leads to a further significant $\mathrm{CO}_{2}$ decrease (Fig. 8a). It shows a clear amplification of the brine mechanism. Indeed, the low diffusion prevents even more the mixing between the carbon enriched bottom waters and the surface. Therefore it amplifies the trapping of carbon in the deep ocean and results in the supplementary simulated $\mathrm{CO}_{2}$ drawdown.

The amplification also applies for $\delta^{13} \mathrm{C}$, especially for $\Delta \delta^{13} \mathrm{C}_{\text {atl }}$ which is increased (Fig. 8b). Indeed, when low diffusion is added, the deep $\delta^{13} \mathrm{C}$ becomes even more negative. The deep (below $-3000 \mathrm{~m}$ ) ocean $\delta^{13} \mathrm{C}$ distribution thus compares far better with the data than in our standard simulation (LGM-std) where the values were too high (Figs. 9 and 10). The upper (above $-2000 \mathrm{~m}$ ) values are greater, resulting in the stronger upper to deep gradient. Hence $\delta^{13} \mathrm{C}$ strongly supports the brine mechanism amplified by low diffusion. Yet even though the Antarctic Bottom Water (AABW) expands and the Glacial North Atlantic Deep Water (GNADW) shoals, the $\delta^{13} \mathrm{C}$ values are still not negative enough in the intermediate south. This suggests that either GNADW should a
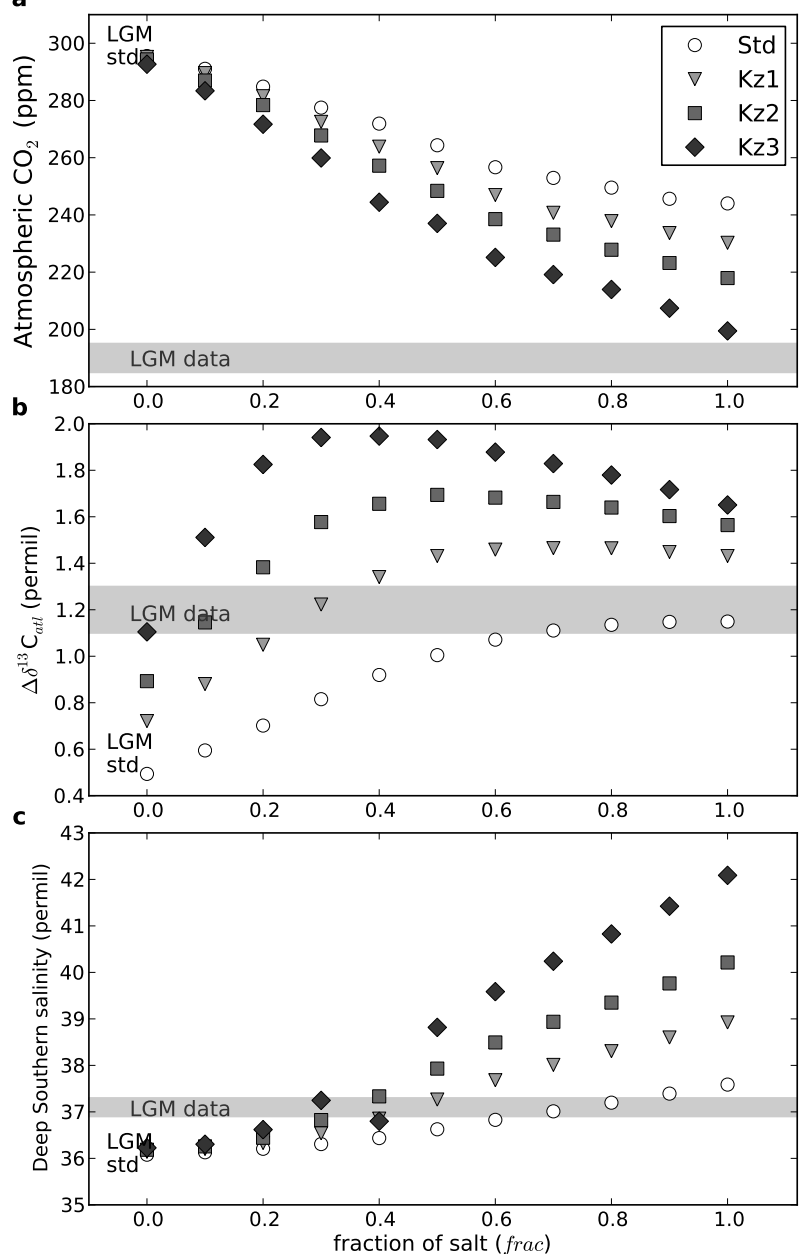

Fig. 8. (a) Atmospheric $\mathrm{CO}_{2}$ concentration, (b) $\Delta \delta^{13} \mathrm{C}_{\mathrm{atl}}$ (mean upper $(-2000 \mathrm{~m}$ to $0 \mathrm{~m})$ to deep $(-5000 \mathrm{~m}$ to $-3000 \mathrm{~m})$ gradient in the Atlantic) and (c) salinity in the deep Southern ocean (Atlantic sector, 50 degrees South, $3626 \mathrm{~m}$ depth) as a function of the fraction of salt released by sea ice formation used for the brine mechanism (fraction of salt frac, $0 \leq f r a c \leq 1$ ) for different vertical diffusion profiles. $\mathrm{Kz0}$ (grey) is the standard profile, Kz1, 2 and 3 are the tested low diffusion profiles (black). The Last Glacial Maximum (LGM) data are from Monnin et al., 2001; Curry and Oppo, 2005; Köhler and Bintanja, 2008; Adkins et al., 2002.

be further reduced and confined to the northern Atlantic, or that another southern water mass existed at intermediate depths (e.g. a Glacial Antarctic Intermediate Water).

\subsection{Impact of brines and low diffusion on oceanic $\Delta^{14} \mathrm{C}$}

The oceanic distribution of $\Delta^{14} \mathrm{C}$ can be modified by two different processes with the brine mechanism. The change of oceanic circulation induced by the transport of salt to the deep ocean alters the mixing of water masses. The mixing is lowered which tends to increase the vertical gradient and 


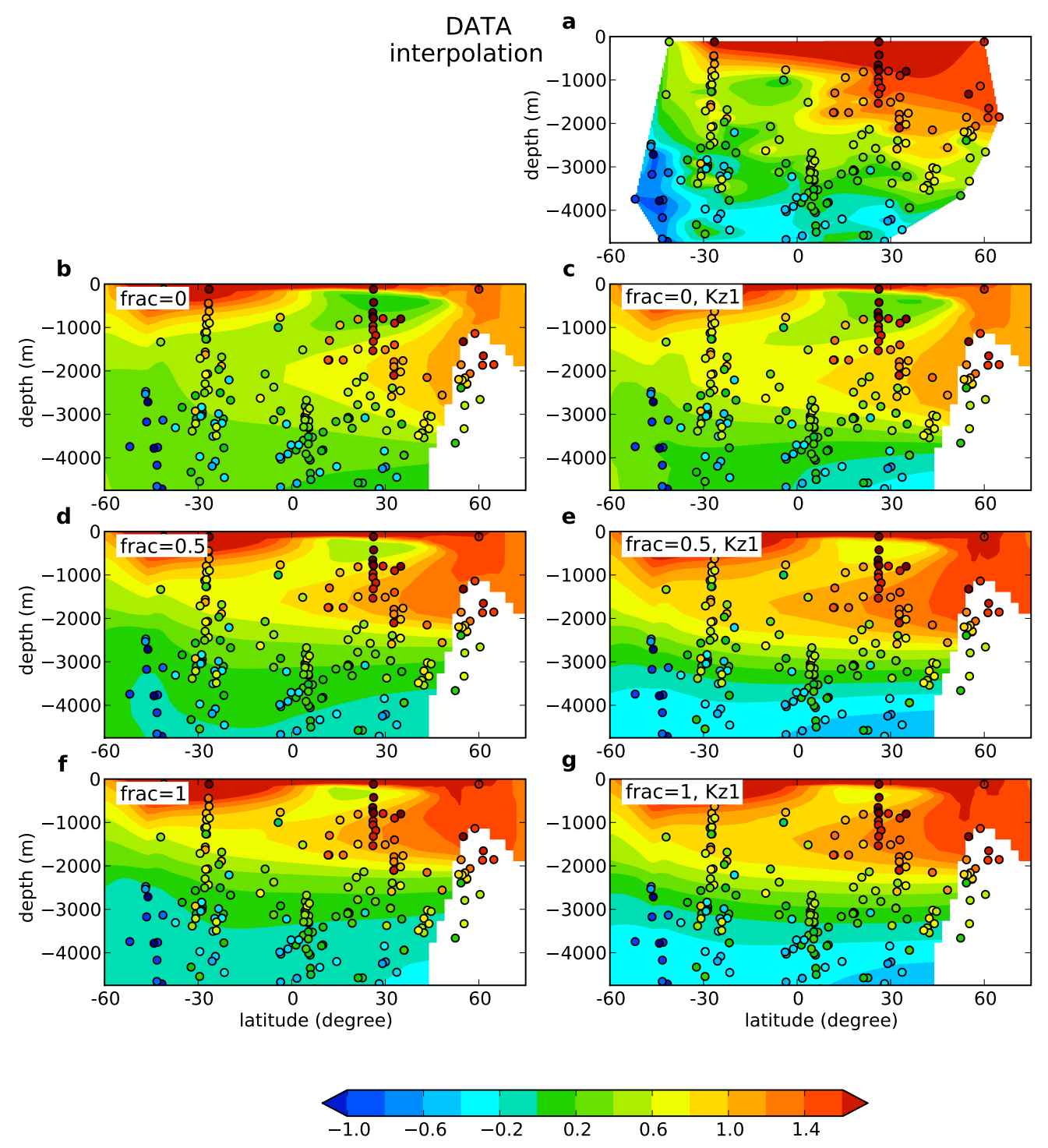

Fig. 9. $\delta^{13} \mathrm{C}(\% \circ)$ distribution in the Atlantic. The dots represent the LGM data (Curry and Oppo, 2005; Köhler and Bintanja, 2008). (a) Interpolation of the data. (b), (c), (d), (e), (f), (g) Modelled $\delta^{13} \mathrm{C}$ distribution: (b), (d), (f) with the standard diffusion profile Kz0 (Fig. 7); (c), (e), (g) with the low diffusion profile Kz1 (Fig. 7). (b), (c) frac =0 (no impact of brines), (d), (e) frac =0.5 (medium impact of brines), (f), (g) frac $=1$ (maximum impact of brines).

lower $\delta^{14} \mathrm{C}$ in the deep ocean. On the opposite, the $\mathrm{DI}^{14} \mathrm{C}$ transport during the sinking of brines brings DIC with high ${ }^{14} \mathrm{C}$ from the surface to the bottom. It then increases the deep $\Delta{ }^{14} \mathrm{C}$ values and lower the vertical gradient. The change of circulation is the prevailing effect and the deep $\Delta^{14} \mathrm{C}$ values become very low (Fig. 11a, c and d). Yet only with the very extreme and probably unrealistic frac value $(f r a c=1)$ can the circulation capture the increased deep-water ages present in the data (Robinson et al., 2005; Skinner et al., 2010).
The low diffusion enhances the vertical gradient as the deep ocean becomes even more isolated. The deep $\Delta{ }^{14} \mathrm{C}$ data values can then be reached with lower frac values. With very low diffusion profiles (Kz2 and 3, Fig. 12), the deep water $\Delta^{14} \mathrm{C}$ become too low showing that the diffusion should be lowered but not as much.

\subsection{Glacial-interglacial carbon cycle changes}

Previous studies with simple box models showed that a reduced Southern ocean vertical mixing rate, which is imposed in the model, can reduce atmospheric $\mathrm{CO}_{2}$ (Paillard 

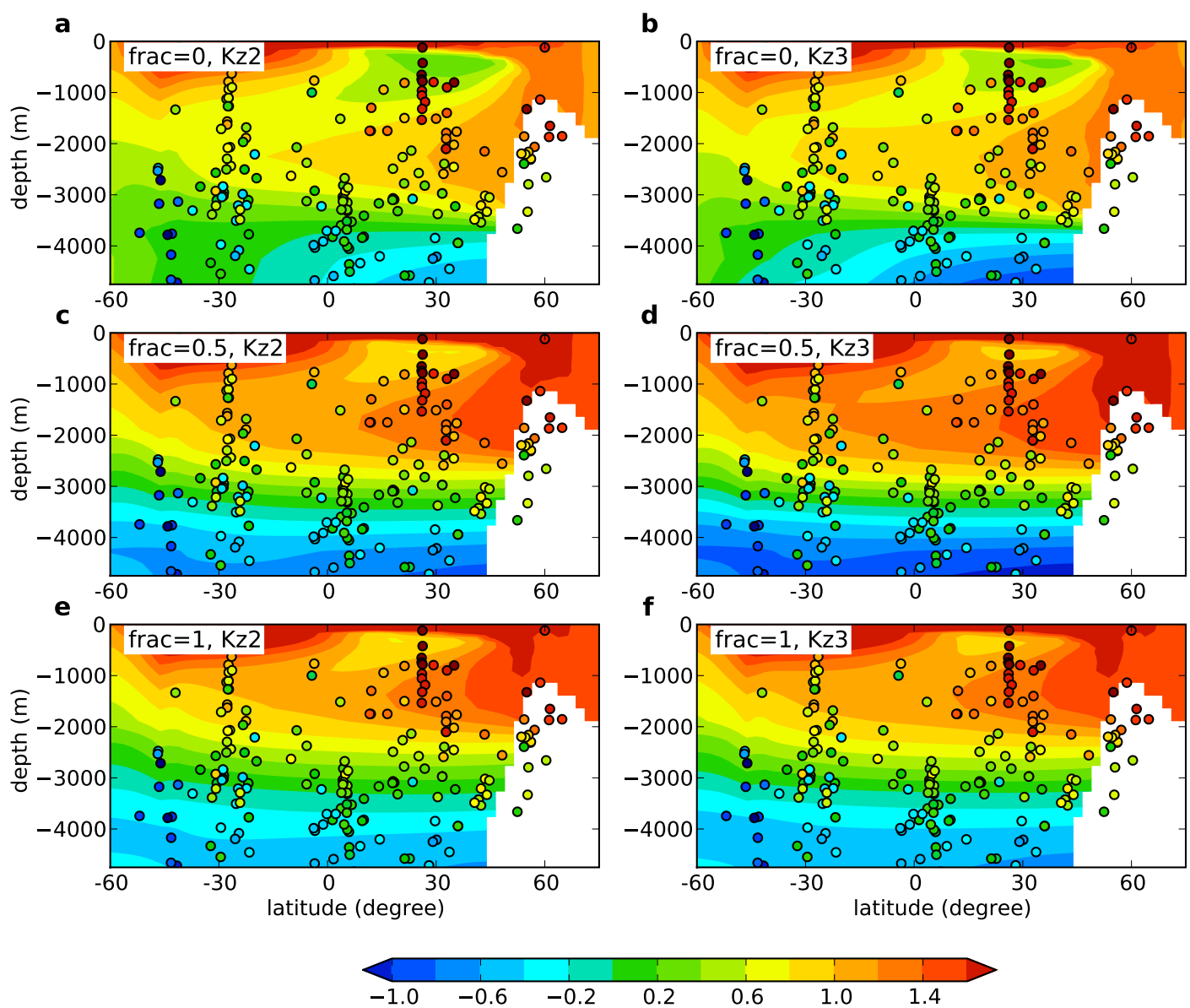

Fig. 10. $\delta^{13} \mathrm{C}(\%)$ distribution in the Atlantic. The dots represent the LGM data (Curry and Oppo, 2005; Köhler and Bintanja, 2008). (a), (b), (c), (d), (e), (f) Modelled $\delta^{13} \mathrm{C}$ distribution: (a), (c), (e) with the low diffusion profile Kz2 (Fig. 7); (b), (d), (f) with the low diffusion profile Kz3 (Fig. 7). (a), (b) frac $=0$ (no impact of brines), (c), (d) frac =0.5 (medium impact of brines), (e), (f) frac $=1$ (maximum impact of brines).

and Parrenin, 2004; Köhler et al., 2005). It also decreases the deep Southern $\delta^{13} \mathrm{C}$ (Köhler et al., 2005). More complex models of intermediate complexity and general circulation showed that changes in the oceanic circulation impacts the $\delta^{13} \mathrm{C}$ distribution in the ocean. Reducing the strength of the meridional overturning circulation by adding fresh water fluxes to the North Atlantic tends to decrease the simulated $\delta^{13} \mathrm{C}$ of the deep ocean in line with data (Tagliabue et al., 2009). Alternatively, imposing a lower vertical mixing by changing the vertical diffusion profile also increases the upper to deep oceanic $\delta^{13} \mathrm{C}$ in agreement with data (Bouttes et al., 2009). However in both cases the associated atmospheric $\mathrm{CO}_{2}$ drawdown remains small compared to the glacial-interglacial change (less than $10 \mathrm{ppm}$ compared to $\sim 90 \mathrm{ppm}$ ).

With the sinking of brines, the necessary change of circulation which leads to an increase of the oceanic vertical $\delta^{13} \mathrm{C}$ gradient is simulated with a more physical mechanism (no artificial fresh water flux is added). Moreover the $\mathrm{CO}_{2}$ drawdown simulated is much more significant. With the maximum effect of the sinking of brines $(f r a c=1)$ the $\mathrm{CO}_{2}$ drawdown is $52 \mathrm{ppm}$. With less extreme values of frac around 0.5, the $\mathrm{CO}_{2}$ decrease is around $30 \mathrm{ppm}$, which can be further amplified by 5 to $15 \mathrm{ppm}$ with vertical low diffusion. frac values around 0.5 are the most plausible values as they are both supported by the comparisons of model results with data and modern observations. Indeed, comparisons between the modelled salinity and $\Delta \delta^{13} \mathrm{C}$ with data are in better agreement for frac values around 0.5 with the low diffusion profile $\mathrm{Kz} 1$ (Fig. 8), as well as $\Delta^{14} \mathrm{C}$ (Fig. 11). Such a frac value is also close to 0.62 which corresponds to the observed $\sim 62 \%$ of the salt flux rapidly released by sea ice formation that is released out of the fjord in the Norwegian Sea (Haarpaintner et al., 2001). Yet, though the simulated $\mathrm{CO}_{2}$ drop is important it is still not enough indicating the need for other processes. 

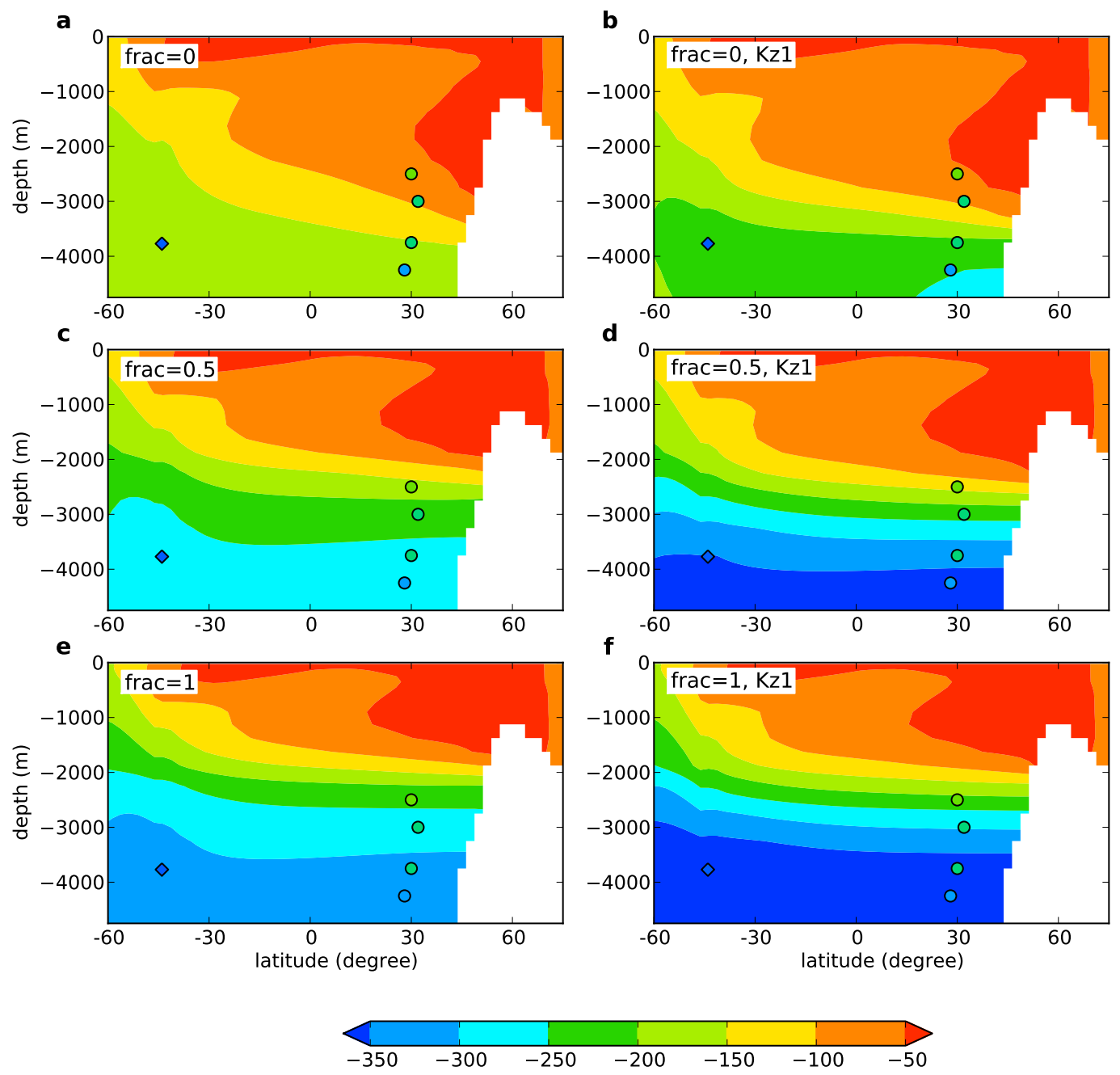

Fig. 11. $\Delta^{14} \mathrm{C}(\% \circ)$ distribution in the Atlantic simulated by the model (where $\Delta^{14} \mathrm{C}=1000 \cdot\left(\frac{\mathrm{DI}^{14} \mathrm{C}}{\mathrm{DIC}}-1\right)$ ). The dots represent the LGM data (Robinson et al., 2005; Skinner et al., 2010). (a), (c), (e) with the standard diffusion profile Kz0 (Fig. 7); (b), (d), (f) with the low diffusion profile Kz1 (Fig. 7). (a), (b) frac =0 (no impact of brines), (c), (d) frac $=0.5$ (medium impact of brines), (e), (f) frac $=1$ (maximum impact of brines).

Hence, although the brine mechanism has the potential to decrease significantly atmospheric $\mathrm{CO}_{2}$, additional mechanisms are also very likely to be involved. In particular, within the already tested mechanisms, the addition of carbonate compensation is a likely candidate, since it would further decrease $\mathrm{CO}_{2}$ by around $30 \mathrm{ppm}$ (Broecker and Peng, 1987; Brovkin et al., 2007). Additionally, modifications to the biological pump (linked to dust reconstructions and phytoplankton stoichiometry) can provide an additional 1025 ppm (Bopp et al., 2003; Tagliabue et al., 2009), as well as increasing carbon export in line with proxy reconstructions. Overall, a combination of low diffusion, carbonate compensation and enhanced biological pump added to the brine mechanism could yield the full range of glacial to interglacial variability of $\mathrm{CO}_{2}$.

\section{Conclusions}

In conclusion, the brine mechanism can lead to a large atmospheric $\mathrm{CO}_{2}$ drop supported by the concomitant simulated changes in oceanic carbon isotope distribution, in agreement with proxy data. We have shown that this $\mathrm{CO}_{2}$ decline is primarily due to the salt transport although the DIC and ALK sink also play a role. Because of the salt transport to the deep ocean the oceanic circulation is modified and the deep ocean becomes more stratified and decoupled from the surface. The abyss is enriched in carbon which is trapped because of the reduced mixing with other water masses. This decrease can be amplified if the simultaneous impact on oceanic vertical diffusion is accounted for. The low diffusion would further reduce the mixing between the deep and upper ocean, hence 

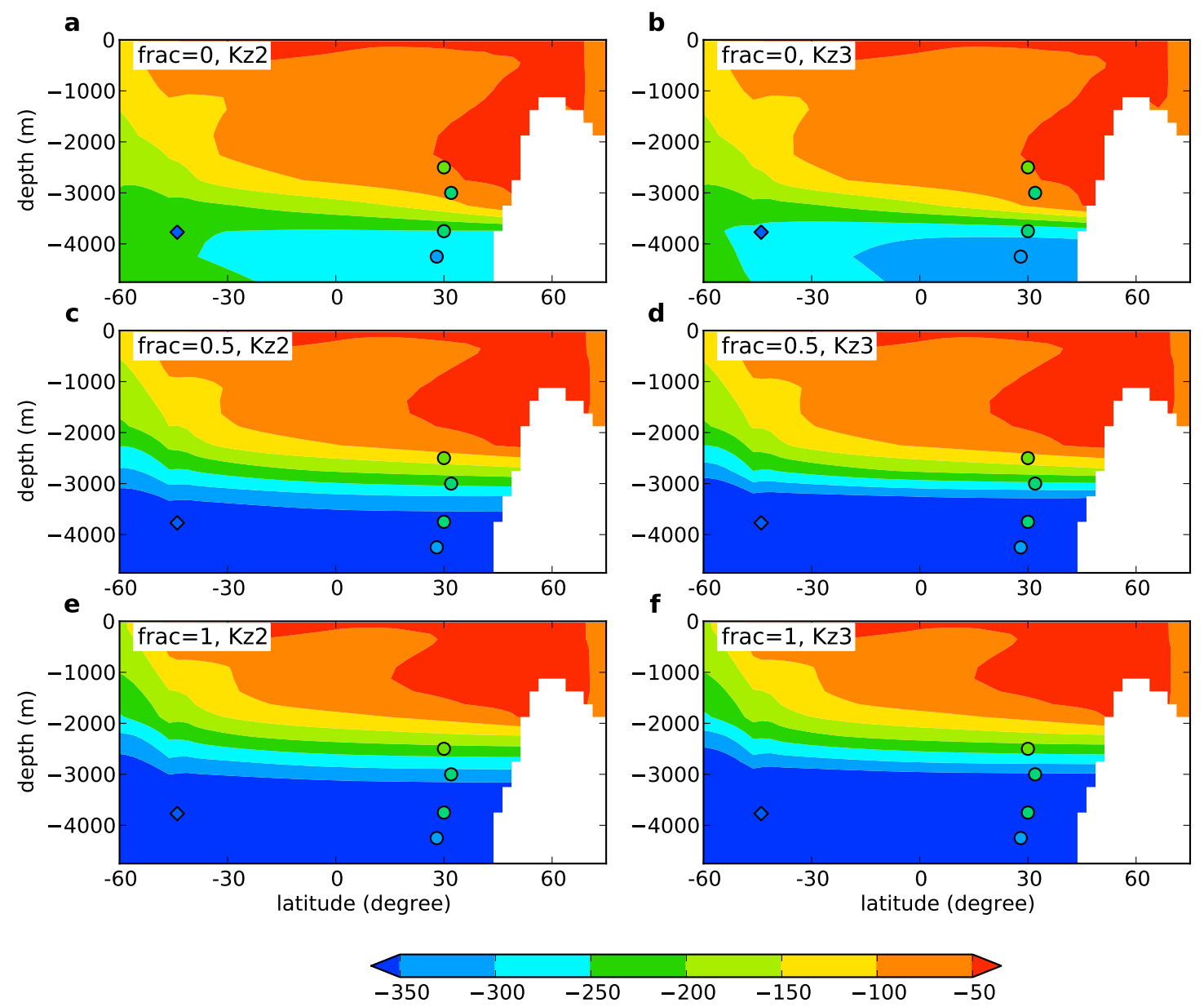

Fig. 12. $\Delta^{14} \mathrm{C}(\% \circ)$ distribution in the Atlantic simulated by the model (where $\Delta^{14} \mathrm{C}=1000 \cdot\left(\frac{\mathrm{DI}}{\mathrm{DIC}}-1\right)$ ). The dots represent the LGM data (Robinson et al., 2005; Skinner et al., 2010). (a), (c), (e) with the low diffusion profile Kz2 (Fig. 7); (b), (d), (f) with the low diffusion profile Kz3 (Fig. 7). (a), (b) frac $=0$ (no impact of brines), (c), (d) frac $=0.5$ (medium impact of brines), (e), (f) frac =1 (maximum impact of brines).

decreasing atmospheric $\mathrm{CO}_{2}$ and increasing the $\Delta \delta^{13} \mathrm{C}_{\text {atl }}$ in line with data. We hypothesize that a combination of the already known carbonate compensation mechanism, iron fertilization, brine mechanism and low diffusion would be sufficient to reach the glacial value of $190 \mathrm{ppm}$. The brine mechanism provides two major features: a physical way of setting the needed glacial deep ocean stratification and a direct connection from surface to deep waters, which is crucial to create a very large deep ocean carbon reservoir. Beyond the understanding of past climate, this mechanism sheds new light on ocean dynamics. Brines have a crucial role in the formation of deep water and should therefore be better accounted for in climate models.
Acknowledgements. We thank Alessandro Tagliabue for comments and ideas, and Laurent Bopp for discussion. We also thank Bill Curry and Peter Köhler for providing the $\delta^{13} \mathrm{C}$ data and Victor Brovkin for his help on the CLIMBER-2 model. We are greatful to Elisabeth Michel for her help with $\Delta^{14} \mathrm{C}$, and to two anonymous reviewers and Gerald Ganssen for their comments which helped improve this manuscript.

Edited by: G. M. Ganssen

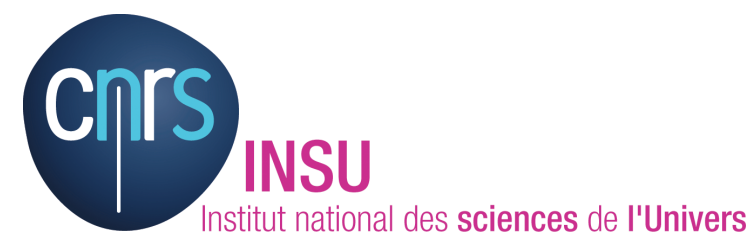

The publication of this article is financed by CNRS-INSU. 


\section{References}

Adkins, J. F., McIntyre, K., and Schrag, D. P.: The salinity, temperature, and $\delta^{18} \mathrm{O}$ of the glacial deep ocean, Science, 298, 17691773, 2002.

Archer, D. and Maier-Reimer, E.: Effect of deep-sea sedimentary calcite preservation on atmospheric $\mathrm{CO}_{2}$ concentration, Nature, 367, 260-263, doi:10.1038/367260a0, 1994.

Archer, D., Winguth, A., Lea, D., and Mahowald, N.: What caused the glacial/interglacial $p \mathrm{CO}_{2}$ cycles?, Rev. Geophys., 38, 159189, 2000.

Archer, D. E., Martin, P. A., Milovich, J., Brovkin, V., Plattner, G.-K., and Ashendel, C.: Model sensitivity in the effect of Antarctic sea ice and stratification on atmospheric $p \mathrm{CO}_{2}$, Paleoceanography, 18(1), 1012, doi:10.1029/2002PA000760, 2003.

Berger, A. L.: Long-term variations of daily insolation and Quaternary climatic changes, J. Atmos. Sci., 35, 2362-2368, 1978.

Berger, W. H.: Increase of carbon dioxide in the atmosphere during Deglaciation: the coral reef hypothesis, Naturwissenschaften, 69, 87-88, 1982.

Bird, M. I., Lloyd, J., and Farquhar, G. D.: Terrestrial carbon storage at the LGM, Nature, 371, 566, 1994.

Bopp, L., Kohfeld, K. E., Quéré, C. L., and Aumont, O.: Dust impact on marine biota and atmospheric $\mathrm{CO}_{2}$ during glacial periods, Paleoceanography, 18(2), 1046, doi:10.1029/ 2002PA000810, 2003.

Bouttes, N., Roche, D. M., and Paillard, D.: Impact of strong deep ocean stratification on the carbon cycle, Paleoceanography, 24, PA3203, doi:10.1029/2008PA001707, 2009.

Broecker, W. S. and Peng, T.-H., eds.: Tracers in the Sea, LamontDoherty Geological Observatory of Columbia University, Palisades, New York, USA, 466-484, 1982.

Broecker, W. S. and Peng, T.-H.: The Role of $\mathrm{CaCO}_{3}$ Compensation in the Glacial to Interglacial Atmospheric $\mathrm{CO}_{2}$ Change, Global Biogeochem. Cy., 1(1), 15-29, 1987.

Brovkin, V., Hofmann, M., Bendtsen, J., and Ganopolski, A.: Ocean biology could control atmospheric $\delta^{13} \mathrm{C}$ during glacialinterglacial cycle, Geochem. Geophys. Geosyst., 3(5), 1027, doi: 10.1029/2001GC000270, 2002.

Brovkin, V., Bendtsen, J., Claussen, M., Ganopolski, A., Kubatzki, C., Petoukhov, V., and Andreev, A.: Carbon cycle, vegetation, and climate dynamics in the Holocene: Experiments with the CLIMBER-2 model, Global Biogeochem. Cy., 16(4), 1139, doi: 10.1029/2001GB001662, 2002a.

Brovkin, V., Ganopolski, A., Archer, D., and Rahmstorf, S.: Lowering of glacial atmospheric $\mathrm{CO}_{2}$ in response to changes in oceanic circulation and marine biogeochemistry, Paleoceanography, 22, PA4202, doi:10.1029/2006PA001380, 2007.

Crowley, T.: Ice Age Terrestrial Carbon Changes Revisited, Global Biogeochem. Cy., 9(3), 377-389, 1995.

Curry, W. B. and Oppo, D. W.: Glacial water mass geometry and the distribution of $\delta^{13} \mathrm{C}$ of $\Sigma \mathrm{CO}_{2}$ in the western Atlantic Ocean, Paleoceanography, 20, PA1017, doi:10.1029/2004PA001021, 2005.

Duplessy, J.-C., Shackleton, N., Fairbanks, R., Labeyrie, L., Oppo, D., and Kallel, N.: Deep water source variations during the last climatic cycle and their impact on the global deepwater circulation, Paleoceanography, 3, 343-360, 1988.

Foldvik, A., Gammelsrød, T., Østerhus, S., Fahrbach, E., Rohardt, G., Schröder, M., Nicholls, K. W., Padman, L., and Woodgate,
R. A.: Ice shelf water overflow and bottom water formation in the southern Weddell Sea, J. Geophys. Res., 109, C02 015, doi: 10.1029/2003JC002008, 2004.

Foster, T. D. and Carmack, E.: Temperature and salinity structure in the Weddell Sea, J. Phys. Oceanogr., 6, 36-44, 1976.

Ganopolski, A., Petoukhov, V., Rahmstorf, S., Brovkin, V., Claussen, M., Eliseev, A., and Kubatzki, C.: CLIMBER-2: A climate system model of intermediate complexity, part II: Model sensitivity, Clim. Dyn., 17, 735-751, 2001a.

Gersonde, R., Crosta, X., Abelmann, A., et al.: Sea-surface temperature and sea ice distribution of the Southern Ocean at the EPILOG Last Glacial Maximum - A circum-Antarctic view based on siliceous microfossil records, Quat. Sci. Rev., 24, 869-896, 2005.

Haarpaintner, J., Gascard, J. C., and Haugan, P. M.: Ice production and brine formation in Storfjorden, Svalbard, J. Geophys. Res, 106, 14001-14013, 2001.

Jahn, A., Claussen, M., Ganopolski, A., and Brovkin, V.: Quantifying the effect of vegetation dynamics on the climate of the Last Glacial Maximum, Clim. Past, 1, 1-7, doi:10.5194/cp-1-1-2005, 2005.

Joughin, I. and Padman, L.: Melting and freezing beneath FilchnerRonne Ice Shelf, Antarctica, Geophys. Res. Lett., 30, 1477, doi: 10.1029/2003GL016941, 2003.

Kikuchi, T., Wakatsuchi, M., and Ikeda, M.: A numerical investigation of the transport process of dense shelf water from a continental shelf to a slope, J. Geophys. Res., 104(C1), 1197-1210, 1999.

Kohfeld, K. E., Quéré, C. L., Harrison, S. P., and Anderson, R. F.: Role of Marine Biology in Glacial-Interglacial $\mathrm{CO}_{2}$ Cycles, Science, 308, 74-78, 2005.

Köhler, P. and Bintanja, R.: The carbon cycle during the Mid Pleistocene Transition: the Southern Ocean Decoupling Hypothesis, Clim. Past, 4, 311-332, doi:10.5194/cp-4-311-2008, 2008.

Köhler, P., Fischer, H., Munhoven, G., and Zeebe, R. E.: Quantitative interpretation of atmospheric carbon records over the last glacial termination, Global Biogeochem. Cy., 19, GB4020, doi: 10.1029/2004GB002345, 2005a.

Köhler, P., Fischer, H., and Schmitt, J.: Atmospheric $\delta^{13} \mathrm{CO}_{2}$ and its relation to $\mathrm{pCO}_{2}$ and deep ocean $\delta^{13} \mathrm{C}$ during the late Pleistocene, Paleoceanography, 25, PA1213, doi:10.1029/ 2008PA001703, 2010.

Luthi, D., Floch, M. L., Bereiter, B., Blunier, T., Barnola, J.-M., Siegenthaler, U., Raynaud, D., Jouzel, J., Fischer, H., Kawamura, K., and Stocker, T. F.: High-resolution carbon dioxide concentration record 650,000-800,000 years before present, Nature, 453, 379-382, doi:10.1038/nature06949, 2008.

MARGO Project Members: Constraints on the magnitude and patterns of ocean cooling at the Last Glacial Maximum, Nat. Geosci., 2, 127-132, doi:10.1038/ngeo411, 2009.

Martin, J. H.: Glacial-Interglacial $\mathrm{CO}_{2}$ change: the iron hypothesis, Paleoceanography, 5, 1-13, 1990.

Matsumoto, K., Sarmiento, J. L., and Brzezinski, M. A.: Silicic acid leakage from the Southern Ocean: A possible explanation for glacial atmospheric $p \mathrm{CO}_{2}$, Global Biogeochem. Cy. , 16(3), 1031, doi:10.1029/2001GB001442, 2002.

Menviel, L., Timmermann, A., Mouchet, A., and Timm, O.: Meridional reorganizations of marine and terrestrial productivity during Heinrich events, Paleoceanography, 23, PA1203, doi: 
10.1029/2007PA001445, 2008b.

Monnin, E., Indermühle, A., Daellenbach, A., Flueckiger, J., Stauffer, B., Stocker, T. F., Raynaud, D., and Barnola, J.-M.: Atmospheric $\mathrm{CO}_{2}$ Concentrations over the Last Glacial Termination, Science, 291, 112-114, 2001.

Nicholls, K. W., Østerhus, S., Makinson, K., Gammelsrød, T., and Fahrbach, E.: Ice-ocean processes over the continental shelf of the southern Weddell Sea, Antarctica: A review, Rev. Geophys., 47, RG3003, doi:10.1029/2007RG000250, 2009.

Opdyke, B. N. and Walker, J. C. G.: Return of the coral reef hypothesis: Basin to shelf partitioning of $\mathrm{CaCO}_{3}$ and its effect on atmospheric $\mathrm{CO}_{2}$, Geology, 20, 733-736, 1992.

Paillard, D. and Parrenin, F.: The Antarctic ice sheet and the triggering of deglaciations, Earth Planet. Sc. Lett., 227, 263-271, 2004.

Peltier, W. R.: Global glacial isostasy and the surface of the iceage Earth: The ICE-5G (VM2) Model and GRACE, Annu. Rev. Earth Planet. Sci., 32, 111-49, doi:10.1146/annurev.earth.32. 082503.144359, 2004.

Petoukhov, V., Ganopolski, A., Eliseev, A., Kubatzki, C., and Rahmstorf, S.: CLIMBER-2: A climate system model of intermediate complexity, part I: Model description and performance for present climate, Clim. Dynam., 16, 1-17, 2000.

Ritz, C., Rommelaere, V., and Dumas, C.: Modeling the evolution of Antarctic ice sheet over the last 420,000 years: Implications for altitude changes in the Vostok region, J. Geophys. Res., 106, 31,943-31,964, 2001.

Robinson, L. F., Adkins, J. F., Keigwin, L. D., Southon, J., Fernandez, D. P., Wang, S.-L., , and Scheirer, D. S.: Radiocarbon Variability in the Western North Atlantic During the Last Deglaciation, Science, 310, 1469-1473, doi:10.1126/science.1114832, 2005.

Rysgaard, S., Glud, R. N., Sejr, M. K., Bendtsen, J., and Christensen, P. B.: Inorganic carbon transport during sea ice growth and decay: A carbon pump in polar seas, Geophys. Res., 112, C03 016, doi:10.1029/2006JC003572, 2007.

Rysgaard, S., Bendtsen, J., Pedersen, L. T., Ramløv, H., and Glud, R. N.: Increased $\mathrm{CO}_{2}$ uptake due to sea ice growth and decay in the Nordic Seas, J. Geophys. Res., 114, 114, doi: 10.1029/2008JC005088, 2009.

Shcherbina, A. Y., Talley, L. D., and Rudnick, D. L.: Direct Observations of North Pacific Ventilation: Brine Rejection in the Okhotsk Sea, Science, 302, 1952-1955, doi:10.1126/science. 1088692, 2003.
Skinner, L. C., Fallon, S., Waelbroeck, C., Michel, E., and Barker, S.: Ventilation of the Deep Southern Ocean and Deglacial $\mathrm{CO}_{2}$ Rise, Science, 328(5982), 1147-1151, doi:10.1126/science.1183627, 2010.

Skogseth, R., Haugan, P. M., and Haarpaintner, J.: Ice and brine production in Storfjorden from four winters of satellite and in situ observations and modeling, J. Geophys. Res., 109, C10 008, doi:10.1029/2004JC002384, 2004.

Skogseth, R., Smedsrud, L. H., Nilsen, F., and Fer, I.: Observations of hydrography and downflow of brine-enriched shelf water in the Storfjorden polynya, Svalbard, J. Geophys. Res., 113, C08 049, doi:10.1029/2007JC004452, 2008.

Stephens, B. B. and Keeling, R. F.: The influence of Antarctic sea ice on glacial-interglacial $\mathrm{CO}_{2}$ variations, Nature, 404, 171-174, 2000.

Tagliabue, A., Bopp, L., Roche, D. M., Bouttes, N., Dutay, J.-C., Alkama, R., Kageyama, M., Michel, E., and Paillard, D.: Quantifying the roles of ocean circulation and biogeochemistry in governing ocean carbon-13 and atmospheric carbon dioxide at the last glacial maximum, Clim. Past, 5, 695-706, doi:10.5194/cp5-695-2009, 2009.

Toggweiler, J. and Samuels, B.: Effect of Sea Ice on the Salinity of Antarctic Bottom Waters, J. Phys. Oceanogr., 25, 1980-1997, 1995.

Toggweiler, J. R.: Variation of atmospheric $\mathrm{CO}_{2}$ by ventilation of the ocean's deepest water, Paleoceanography, 14(5), 571-588, 1999.

Toggweiler, J. R., Russell, J. L., and Carson, S. R.: Midlatitude westerlies, atmospheric $\mathrm{CO}_{2}$, and climate change during the ice ages, Paleoceanography, 21, PA2005, doi:10.1029/ 2005PA001154, 2006.

Wakatsuchi, M. and Ono, N.: Measurements of Salinity and Volume of Brine Excluded From Growing Sea Ice, J. Geophys. Res. 88(C5), 2943-2951, 1983.

Watson, A. J. and Garabato, A. C. N.: The role of Southern Ocean mixing and upwelling in glacial-interglacial atmospheric $\mathrm{CO}_{2}$ change, Tellus B, 58(1), 73-87, doi:10.1111/j.1600-0889.2005. 00167.x, 2005.

Whitworth, T. and Nowlin, W.: Water Masses and currents of the Southern Ocean, J. Geophys. Res., 92, 6463-6476, 1987. 